\title{
Monetary Institutions and the Political Survival of Democratic Leaders
}

\author{
William R. Cliark \\ University of Michigan \\ Sona N. Golder \\ Pennsylvania State University \\ AND \\ Paul PoAst \\ Rutgers University
}

\begin{abstract}
According to the political business cycle literature, survival-maximizing leaders will manipulate whatever macroeconomic policy instruments they have at their disposal in order to retain power. However, an obvious implication of the political business cycle literature has not previously been adequately tested: does having the ability to manipulate macroeconomic policy instruments actually allow leaders to stay in office longer? We argue that elected leaders who have neither fiscal nor monetary instruments available for electoral purposes will find it more difficult to survive in office. We test this claim using data from 19 OECD countries in the latter part of the twentieth century when the degree of capital mobility in the international economy was high. We find that access to macroeconomic instruments does help leaders retain office, but that these instruments are only effective for leaders who have been in office for at least 7 years.
\end{abstract}

The existence of political business cycles (PBC) - the short-term manipulation of the economy by survivalseeking leaders for the sole purpose of political gain, even if that gain comes with long-term economic consequences-has been long studied by scholars (Nordhaus 1975; MacRae 1977; Tufte 1978; Keech 1995). The idea of PBCs is intuitive (survival-maximizing politicians stimulate the economy just prior to an election because retrospective voters will reward them for doing so even if such stimulus increases inflation and, therefore, reduces real wages), but an obvious implication of the PBC literature has not been adequately tested: does having the ability to induce a PBC actually help leaders survive? The fact that this question has received little attention is surprising, given that, at the end of the day, enhancing political survival is the entire point of inducing a PBC.

Addressing this question requires keeping in mind that PBCs are context specific (Clark 2003). In particular, the high degree of capital mobility in the international economy since the late 1970 s means that the choice of exchange rate regime has a substantial impact on the ability of leaders to use fiscal and monetary levers to manipulate the economy. In democracies where financial capital is free to enter and exit the country, leaders can engage in monetary expansions prior to elections if the exchange rate is flexible and the central bank is not independent. Leaders can engage in fiscal expansions prior to elections if the exchange rate is fixed (Clark and Hallerberg 2000). If, however, the exchange rate is flexible and the central bank is independent, elected leaders will have neither fiscal nor monetary instruments available for electoral purposes. Indeed, Clark (2003) finds that when context-dependent, electorally motivated manipulations of monetary and fiscal policy occur, they produce expansions in national income and reductions in unemployment in pre-electoral periods.

We should not assume that governments face identical incentives to manipulate the economy at each election, however. Instead, as Schultz argues, "incentives for governments to engineer economic cycles can vary greatly from one election to the next depending upon their political needs at the time"' (Schultz 1995:81). For instance, if the government goes into the election relatively sure that it will be re-elected, then it has substantially less incentive to manipulate the economy than when it faces much tougher prospects of re-election. Moreover, the government should want to manipulate the economy only when necessary since, according to Schultz, by potentially damaging the economy after the very short term, the leader can harm the governing party's reputation down the road.

If we accept that PBCs do occur in some contexts, then the question is whether leaders who find themselves in such contexts are able to stay in office longer than would otherwise be the case. This is an open question at present. One study that has considered the impact of monetary institutions on political survival is Bernhard and Leblang (2002). However, because they are interested in how different monetary institutions help government coalition partners mitigate intra- and inter-party conflicts, not in how different monetary institutions influence the length of time a leader stays in office, they do not focus on the length of time a particular government or prime ministerial party remains in power. Instead, Bernhard and Leblang (2002) seek to explain the proportion of the maximum electoral term 
available that a cabinet fulfills. ${ }^{1}$ Thus, it is not clear that the Bernhard and Leblang analysis explains political survival as we conceptualize it in this paper. Indeed, a recent study has shown that the percentage of the potential term that a government fulfills is not a good proxy for the length of time a cabinet stays in office (Conrad and Golder 2010).

In contrast, we seek to evaluate how monetary institutions affect the amount of time a leader remains in office. The importance of evaluating the survival of leaders is becoming more prevalent in political science, and in this respect, we follow recent literature such as Brownlee (2009), McGillivray and Smith (2008), Chiozza and Goemans (2004) and Bienen and van de Walle (1991). We evaluate leader tenure by considering when a leader experiences political death, which we define as removal from office that meets one of three conditions: (i) the leader resigns or retires for any reason other than declining health; (ii) the leader loses a general election; or (iii) the leader is term limited, but that leader's party loses office in the terminal election.

The next section briefly reviews the theory of contextspecific macroeconomic policy manipulation. We develop the hypothesis that leaders who possess instruments with which to engineer pre-electoral macroeconomic expansions should survive longer in office than those who do not. Recognizing that the need to manipulate macroeconomic policy is context dependent, we also discuss the proposed mechanism that links possible leader survival to monetary institutions, hypothesizing that leaders presiding over slower growth rates are more likely to be removed from office than other leaders. The third section describes our research design and data. We test our hypothesis using data from 19 OECD countries from 1972 to 1999 , including original data that we collected on the reasons for leader removal. The fourth section presents our model and results. Consistent with our expectations, we find that having control of macroeconomic policy tools enhances leader survival, though, somewhat surprisingly, we find that these tools only help survival for long-serving leaders. Specifically, we find that these instruments are only effective for leaders who have been in office for at least 7 years. In the fifth section, we discuss links to other literatures that might offer an explanation for this surprising finding.

\section{Monetary Institutions, Economic Policy, and Leader Survival}

Standard open economy macroeconomic theory is relatively straightforward. Absent capital mobility, both monetary policy and fiscal policy can be used to affect national income. After capital mobility is introduced, monetary policy is effective only when the exchange rate is allowed to fluctuate, and fiscal policy is effective only when the exchange rate is fixed (Mundell 1963). Consequently, in the absence of capital mobility, incumbents have two macroeconomic policy instruments at their disposal, but

\footnotetext{
${ }^{1}$ For example, in a country with a constitutional inter-election period of 4 years, a cabinet that forms immediately after an election and lasts for 3 years would be coded 0.75 , because it had fulfilled $75 \%$ of the maximum electoral term available. If a new cabinet formed and stayed in office for the remaining year prior to the constitutionally mandated election then that cabinet would be coded as 1.0 because it would have remained in office for the maximum amount of time possible. Although the first cabinet lasted three times longer than the second cabinet, it would be coded as being less durable.
}

with capital mobility they are forced to choose between fiscal and monetary instruments.

Central bank independence adds a further complication for incumbents. Assuming central bankers and incumbents differ in their policy preferences, the independent status of the bank drives a wedge between what the leader would like to do and what she can do. We assume, following existing literature, that political leaders desire to remain in power. The claim here is not that independent central bankers can routinely ignore the policy preferences of their political principals, but that independence creates friction in at least one of the mechanisms by which incumbents attempt to prolong their tenure.

Clark and Hallerberg (2000) draw on these key macroeconomic insights to explain why political business cycles occur in some times and places but not others. They theorize and find evidence to support the notion that, when macroeconomic conditions permit doing so, leaders vigorously manipulate macroeconomic policy instruments in pre-electoral periods. For instance, when capital mobility is limited and the central bank is dependent, leaders have both monetary and fiscal policy at their disposal and, therefore, can induce pre-election expansions. In marked contrast, when capital is mobile, the exchange rate is allowed to fluctuate, and the central bank is independent, leaders have autonomous control over neither policy instrument.

Table 1 summarizes this argument. Each cell of Table 1 characterizes a different combination of institutional arrangements and identifies the policy tools available to leaders under that particular set of conditions. Because leaders can only induce political business cycles under certain conditions, we expect that only some leaders will, in fact, be able to manipulate monetary or fiscal policy. In what follows, we test whether leaders having macroeconomic policy autonomy actually helps them survive longer in office. According to the PBC literature, we should find that the presence of particular monetary institutions will help incumbents retain office, while other combinations of monetary institutions will not.

Our argument suggests that when capital is mobile, political survival should be a function of, among other things, whether the central bank is independent and the choice of the exchange rate regime. Table 1, for example, shows that when capital is mobile, the exchange rate is flexible, and the central bank is highly independent (cell f), the incumbent controls neither survival-enhancing policy instrument. If our argument is correct, a movement away from this condition should increase the survival chances of the incumbent. For example, it should be the case that a shift to a dependent central bank (holding capital mobility and the exchange rate regime constant, that is, going from from cell $f$ to cell $e$ ), should enhance the survival prospects of the incumbent.

TABle 1. Macroeconomic Tools Available to Leaders under Alternative Monetary Institutions

\begin{tabular}{|c|c|c|c|}
\hline & & $\begin{array}{c}\text { Dependent } \\
\text { Central Bank }\end{array}$ & $\begin{array}{l}\text { Independent } \\
\text { Central Bank }\end{array}$ \\
\hline $\begin{array}{c}\text { No capital } \\
\text { mobility }\end{array}$ & & $\begin{array}{l}\text { (a) Monetary and } \\
\text { fiscal policy }\end{array}$ & (b) Fiscal policy \\
\hline \multirow[t]{2}{*}{$\begin{array}{l}\text { Capital } \\
\text { mobility }\end{array}$} & $\begin{array}{l}\text { Fixed } \\
\text { exchange rate }\end{array}$ & (c) Fiscal policy & (d) Fiscal policy \\
\hline & $\begin{array}{l}\text { Flexible } \\
\text { exchange }\end{array}$ & (e) Monetary policy & (f) No instruments \\
\hline
\end{tabular}


Similarly, starting again at our baseline case, a change to a fixed exchange rate (from cell $f$ to cell $d$ ) should give the incumbent newfound power to use fiscal policy to enhance its survival in office. Finally, a shift from our base line case that involves both a reduction in central bank independence and an adoption of a fixed exchange rate (from cell $f$ to $c$ ) also gives the incumbent potentially survival-enhancing control over fiscal policy, where it previously had no such control.

We can now state the following two hypotheses:

Hypothesis 1: When capital is mobile and the central bank is independent, incumbents with fixed exchange rates should survive longer in office (have lower hazard rates) than those with flexible exchange rates.

Hypothesis 2: When capital is mobile and exchange rates are flexible, incumbents with dependent central banks should survive longer in office (have lower hazard rates) than those with independent central banks.

One assumption of the argument thus far is that an important mechanism by which leaders lose office is an inability to produce the macroeconomic outcomes needed to ensure their political survival. If this is indeed the mechanism, then two additional steps in the causal process should be true. First, incumbents who possess the tools necessary to manipulate the economy for survivalmaximizing purposes, should do so. Second, voters should remove leaders who fail to produce the macroeconomic outcomes they desire. There are two large literatures that examine these steps in the causal process: on the one hand is the literature on political business cycles and on the other hand is the literature on economic voting. With respect to the former, Clark and Hallerberg (2000) and Clark (2003) provide substantial evidence that leaders will indeed aggressively manipulate whatever monetary or fiscal policy instruments are available in the run up to elections. With respect to the latter, numerous studies identify an association between incumbent vote share and various macroeconomic indicators (for example Duch and Stevenson 2008).

However, because the modal way in which leaders are removed from office does not involve the ballot box, but rather occurs through resignation (see Table 2 in the next section), the literature on economic voting cannot be uncritically applied here. If our argument is correct, we should observe a broader connection between the macroeconomy and the political survival of long-serving leaders. Specifically, it should be the case that poor macroeconomic conditions ought to place incumbents in peril of being removed from office, but we are catholic with respect to the means by which this is accomplished. Voters may remove leaders who produce economic outcomes they dislike when given the chance, but party elites may do the job for them. Determining which mode of removal will occur is beyond the scope of this study, but our argument suggests that the economic voting literature may be flawed in that it mistakes $a$ mechanism of leader removal for the mechanism of leader removal. Consequently, merely citing studies that show that voters remove leaders during bad macroeconomic times does not suffice in establishing our proposed mechanism. Instead it would be useful to demonstrate the connection between poor macroeconomic performance and leader removal.
TABLE 2. Leader Data

\begin{tabular}{|c|c|}
\hline $\begin{array}{l}\text { Reason for } \\
\text { Removal }\end{array}$ & $\begin{array}{l}\text { Number of } \\
\text { Leaders }\end{array}$ \\
\hline \multicolumn{2}{|l|}{ Leader removal 1972-1999, by type } \\
\hline \multicolumn{2}{|l|}{ "Political deaths", } \\
\hline Lost election & 44 \\
\hline $\begin{array}{l}\text { Term limit (not succeeded } \\
\text { by co-partisan) }\end{array}$ & 1 \\
\hline Resign (political) & 65 \\
\hline \multicolumn{2}{|l|}{ "Extra political", } \\
\hline $\begin{array}{l}\text { Term limit (succeeded } \\
\text { by co-partisan) }\end{array}$ & 2 \\
\hline Resign (health) & 5 \\
\hline Death & 3 \\
\hline End of sample & 18 \\
\hline \multicolumn{2}{|c|}{ Leader tenure data summary statistics (1972-1999) } \\
\hline Mean tenure (in years) & 3.93 \\
\hline Median tenure (in years) & 2.49 \\
\hline Minimum tenure (in years) & $\begin{array}{l}0.15 \text { (Moore, } \\
\text { New Zealand) }\end{array}$ \\
\hline Maximum tenure (in years) & $\begin{array}{c}25.7 * \text { (Kekkonen, } \\
\text { Finland) }\end{array}$ \\
\hline 90 percentile (in years) & 8.77 \\
\hline 75 percentile (in years) & 5.07 \\
\hline 25 percentile (in years) & 1.26 \\
\hline
\end{tabular}

(Notes. Data compiled using Zarate's Political Collections dataset and Keesing's Record of World Events.

*Kekkonen had already been in office for 16 years by 1972 ; only the final 10 years of his term are included in our data.)

Hypothesis 3: Increased economic growth reduces the leader's risk of being removed from office (reduces the hazard rate).

\section{Research Design}

In our analysis, we must measure the amount of time leaders have been in office and whether those leaders left office for political reasons. Additionally, we must take into account the effectiveness of monetary institutions during the Bretton-Woods era compared to the postBretton Woods era as well as political business cycles. Finally, we must identify other factors likely to affect the survival of democratic leaders that we might need to control for in our empirical analyses. This section details our operationalization of these variables.

\section{Operationalizing Leader Tenure and "Political Death"}

To create a dependent variable measuring the tenure in office of political leaders, we must first identify when leaders leave office and, second, if their removal can be classified as a "political death." Unfortunately, existing data sets on leader removal, such as the Archigos data set by Goemans, Skrede Gleditsch, and Chiozza (2009), are not well suited for this purpose. Although the Archigos data set is extensive, it focuses on evaluating "irregular" causes of leader removal, such as coups and forceful removal by another state. Consequently, it codes all removals by the "prevailing rules, provisions, conventions, and norms of the country" as simply "regular" removals (Goemans et al. 2009:272). However, we need to know the exact "regular" cause that resulted in the leader's loss of office.

Therefore, we create an original data set of leader removal in 19 OECD countries from 1972 to 1999 . We 
use the date a leader takes office and the date a leader leaves office to measure the leader's tenure. Leaders in our data set (described in detail later) are fairly evenly distributed across the six monetary regimes specified in Table $1 .^{2}$ The data set identifies whether a leader leaves office due to a resignation induced by scandal, a resignation induced by a lack of popularity (and, hence, the party's desire to change leadership), a resignation induced by health concerns, a loss of an election, death in office, or a term limit. We draw on two sources to construct this data set. First, we obtain a listing of political leaders, their party, and their dates in office from Zarate's Political Collections dataset. Second, each leader's reason for leaving office is coded with information from Keesing's Record of World Events.

Excluding interim leaders (Aoki of Japan in 2000; Zolotas of Greece in 1989/1990; Poher of France in 1974; Ito of Japan in 1980; and Grivas of Greece in 1989), military dictators (Franco of Spain; Papadopoulos and Gizikis of Greece), monarchs (Constantine II and Paul I of Greece), and transitional leaders (Juan Carlos of Spain), we have information on the loss of leadership for 138 leaders in 19 countries over a 28-year period. ${ }^{3}$

Having constructed this data set, we define "political death" as when an individual leader leaves office for nonhealth-related reasons and was not term-limited. We code "political death" using the following rules. If a leader resigns or retires for any reason other than declining health, we code this as a political death. For example, since Giulio Andreotti resigned as Prime Minister of Italy in 1992 due to a poor showing by the Christian Democrats in legislative elections, this is coded as a political death. However, the resignation of Greek Prime Minister Andreas Papandreou in 1996 due to declining health is not coded as a political death. If a leader loses a general election, we code this as a political death. Hence, despite serving in office for 16 years, Helmut Kohl is ultimately coded as a political death as he lost the 1998 German general election to Gerhard Schroeder. Although our interest is in the political life and death of individual leaders, the fact that some leaders are term-limited presents a challenge for our definition of political death. Admittedly, as Table 2 shows, a very small number of leaders in our sample actually face term limits. Nevertheless, one must think carefully about how to define political death as it relates to term-limited leaders. In the analyses that follow, if a leader is term-limited, but that leader's party loses office in the succeeding election, this is coded as a political death. For example, when Ronald Reagan, a Republican, left office in January 1989, another Republican, George H. W. Bush, was to be sworn in as the next President. As the Republican party maintained control of the Presidency, this is not coded as a political death. ${ }^{4}$ Our approach to dealing with term-limited leaders is based on the possibly heroic assumption that leaders continue to care about

${ }^{2}$ The countries in our data set are Australia, Austria, Belgium, Canada, Denmark, Finland, France, Germany, Greece, Ireland, Italy, Japan, Netherlands, New Zealand, Norway, Spain, Sweden, United Kingdom, and the United States.

Some leaders had experience with more than one combination of monetary institutions, so the number of leaders associated with each type of institution do not sum to the number of leaders in the data set. Refer back to the different combinations of institutions presented in Table 1. Specifically, in our data cell (c) has 54 leaders (215 leader years), cell (d) has 28 leaders (176 leader years), cell (e) has 39 leaders (143 leader years), and cell (f) has 24 leaders (115 leader years).

We do not happen to have examples of term limited leaders whose party lost power in our sample. their party's electoral performance even when they know they will be stepping down from power themselves. As robustness tests, we tried other approaches and found that none changed our results in a substantive way. ${ }^{5}$

Table 2 provides details of this data. ${ }^{6}$ The top portion of Table 2 tabulates the number of leaders from our sample coded for each reason of "political death." The largest category is political resignations, comprising nearly half the sample (65 of 138 leaders). Italy (21) has the most resignations, followed closely by Japan (14). We should note that of these resignations, four were related to scandals (Nixon, USA, 1974; Nakasone, Japan, 1987; Uno, Japan, 1989; Hosokawa, Japan, 1994) and four were ostensibly retirements (Sato, Japan, 1972; Karamanlis, Greece, 1980; Haughey, Ireland, 1992; Carlsson, Sweden, 1996). By treating all resignations not brought on by an acute illness as political deaths, we are implicitly assuming that leaders presiding over better macroeconomic conditions would be able to survive scandals and willing to postpone retirement.

The bottom portion of Table 2 provides descriptive statistics of the leader tenure data. As the majority of leaders leave office within the first few years of tenure, becoming a long-serving leader (in office past 5 years or more) is rare. However, as we will show, it is this rare breed of long-serving leaders who benefit most, electorally speaking, from having macroeconomic policy autonomy. ${ }^{7}$

\section{Operationalizing the Key Explanatory Variables}

The key explanatory variables capture the monetary institutions under which each leader operated. These sometimes vary over the tenure of a particular leader, and our estimation method allows us to take account of this. Fixed Exchange Rate is a dichotomous variable based on the IMF's Exchange Rate Arrangements and Exchange Restrictions (various years). Dependent Central Bank equals 1 if the country's legal independence measure (Cukierman, Webb, and Neyapti 1992) is below the sample median. These measures were taken from Clark (2003).

\section{Operationalizing Capital Mobility}

Some scholars, such as Bernhard and Leblang (2002), operationalize capital mobility with a country-specific variable. Specifically, these scholars use as a proxy for barriers to the movement of assets across borders the Restrictions on International Transactions compiled by Quinn (1997). However, we treat capital mobility as a system level variable and only use the Quinn measure as a

\footnotetext{
${ }^{5}$ For example, one possibility would be to treat term-limited leaders at the end of their final term as censored. However, one could argue that term limits are not truly exogenous terminations imposed on leaders; leaders in such countries know full well that they face a term limit when they enter the final term. Another possibility would be to add a dummy variable for each term-limited leader's final term, to account for the fact that leaders in their final term might behave differently. Finally, we could re-do our analyses after dropping the two countries in our sample with term limits (the United States and Finland). None of these alternate approaches change the results substantially. Results for these additional analyses are available from the authors on request.

6 The complete data set of leader removal is available from the authors by request.

There is some uncertainty regarding the proper coding of Finland. Specifically, there is a debate about whether the President should be coded as the leader of Finland for the entire time frame or whether the leader of Finland should be coded as the President up to 1981 and the Prime Minister should be coded as the leader after 1981. We conduct all tests with both codings, and the results are not altered. Therefore, the results reported here are with the President coded as the leader of Finland.
} 
robustness check. ${ }^{8}$ That is, capital mobility is a feature of the international system that induces countries to reduce their barriers, not because doing so increases capital mobility, but because doing so was simply a recognition of reality: the ability of governments to effectively control flows of capital into and out of their countries had been severely curbed. For this reason, many scholars believe that the end of the Bretton Woods system accompanied a structural break in the degree of capital mobility in the international economy (Webb 1991; Andrews 1994; Clark 2003). We follow suit, by assuming that capital is mobile for countries from 1972 onward. Some may argue that the global financial system did not become fully mobile in 1972, but that this occurred later (in the early 1980s after the UK and other European nations removed capital controls). Therefore, we re-estimate the model using various years between 1972 and 1985 (the latest possible date by which one could reasonably say the global financial system was not mobile) to indicate the start of capital mobility. Doing so does not alter our results. ${ }^{9}$

\section{Operationalizing Economic Growth}

Finally, to test the third hypothesis, we combined our data on leader survival with yearly data on real GDP growth taken from Garrett (1998). We have argued that when leaders confront an independent central bank, mobile capital, and a flexible exchange rate, they will lack the necessary tools to produce macroeconomic expansions needed to stave off challenges to their political survival. This test will allow us to see whether leaders presiding over good economic times actually survive longer than those that do not.

\section{Other Factors Affecting the Survival of Democratic Leaders}

The general literature on leader survival suggests some additional factors that may well affect the length of time a leader is able to stay in power. We might expect that leaders who participate in multi-party coalitions survive at different rates than leaders who head single-party majority governments. It is not immediately clear, however, which arrangement should improve a leader's tenure. On the one hand, leaders of single-party majority governments will have the ability to respond quickly to exogenous shocks and will have little opposition when they want to use macroeconomic policy instruments for political purposes. On the other hand, when things go awry, voters will find it easier to place the blame on single-party majorities than parties in large coalitions. Single-party majority governments, therefore, are more autonomous in their control of policy, but are also more likely to be held accountable (Powell 2000). ${ }^{10}$ Controlling for type of

\footnotetext{
${ }^{8}$ Specifically, all countries that have a Quinn (1997) Restriction on International Transactions score above the sample's median value (75 on a $0-100$ scale) are treated as having mobile capital. We find the effects of central bank independence and exchange rate regime to be nearly identical to the results presented in the text. Replication files for conducting this robustness check are available upon request.

9 Results from this robustness check are available upon request.

${ }^{10}$ We can think of minority governments as de facto coalition governments, as the government relies on support from opposition parties to remain in power and pass legislation. But they, arguably, will find it difficult to share blame for bad outcomes with "shadow" coalition partners. Consequently, one might think of minority governments as cursed with the worst of both worlds. They lack both the autonomy to respond quickly that single party majority governments possess and the ability to share blame with coalition partners (Powell 2000). However, some scholars have argued that what keeps minority parties in power is that they are "strong" parties in the sense that there is no viable alternative to their rule (Laver and Shepsle 1996). In this sense, we might expect them to have the longest tenure.
}

government is important because scholars have argued that commitments to central bank independence will lack credibility when made by single-party majority governments (Moser 1999; Keefer and Stasavage 2002). We include a dummy variable indicating whether a singleparty majority controls the government or not. This variable was coded with data from Woldendorp, Keman and Budge (2000) and supplemented where necessary from country reports from the European Journal of Political Research or media accounts. ${ }^{11}$

While we have focused on the manipulation of macroeconomic policy instruments by survival-maximizing incumbents, another possibility is that leaders survive by judiciously timing elections to take advantage of good economic times that may be largely outside their control (Smith 1996; Palmer and Whitten 2000; Kayser 2005). If leaders "surf" the economy rather than "manipulate" it, then leaders should survive longer in countries with endogenous election timing, and their survival should be unrelated to the monetary institutions that we have identified as crucial to their ability to manipulate the economy. Alternatively, it is possible that surfing and manipulating are substitutes-perhaps leaders are more likely to surf when they do not have the instruments that are required to manipulate. Leaders ought to be more reluctant to adopt monetary institutions that inhibit the ability to manipulate the economy in systems with exogenously timed elections. Therefore, we control for whether leaders can easily determine election timing. We rely on coding by Kayser (2006) to identify "premier timing", cases in our data set. As Kayser (2005:18) notes, of the 19 countries in our data set, only Norway and the United States "fully preclude early elections." Neither country ever has endogenously determined elections, whereas they can occur in the other countries. However, the ability of leaders to determine election dates is not equally unconstrained across the sample of "endogenous-timing countries" and so we follow Kayser's practice of dividing this set of countries into those that have premier timed and those that do not. ${ }^{12}$ In our sample, twelve of the nineteen countries are premier-timing.

Another institutional feature that is likely to influence leadership survival is the number of electoral districts. The number of electoral districts captures the degree to which the legislature is geographically fractionalized. When the legislature is carved up into many small constituencies, it may be possible for leaders to use targeted government spending to increase their survival in office even when mobile capital and flexible exchange rates render such spending ineffective in terms of the macroeconomy (Weingast, Shepsle, and Johnsen 1981; Franzese 2002; Franzese and Nooruddin 2004). The number of electoral districts may also influence the choice of exchange rate regime or degree of central bank independence. To see why, imagine an incumbent in a system with many small electoral districts. When capital is mobile, a fixed exchange rate will allow

\footnotetext{
${ }^{11}$ For the United States, we coded as single-party majority government those cases in which the president and a majority in both houses of Congress were controlled by the same party (Laver and Shepsle 1991). For all other countries in the sample, Woldendorp, Keman, and Budge (2000) explicitly code government types, indicating whether a government consists of a singleparty majority or not.

12 According to Kayser, the distinction is as follows: "Premier-timing requires that the incumbent executive have the de jure and de facto ability to initiate dissolution and early elections either directly or through a parliamentary majority, whereas the non-premier category includes countries in which early elections are limited to extraordinary circumstances or election dates are set by any actor other than the government" (Kayser 2006:442).
} 
targeted fiscal expenditures to also have a broader macroeconomic effect, thus making fixed exchange rates more attractive. Alternatively, one might think incumbents would want to complement targeted fiscal expenditures with the ability to control the broader macroeconomy with monetary policy, making flexible exchange rates more attractive. Either way, the choice of exchange rate regime would be correlated with the number of electoral districts and excluding this variable from our analysis could bias our results. ${ }^{13}$ Our measure of geographic fragmentation of the legislature, the number of electoral districts, is taken from Golder (2005). As we expect a decreasing marginal effect in the number of districts, we will use the natural log of the number of districts rather than the actual number of districts.

\section{The Model and Results}

We test our hypotheses using survival (event history) analysis. The central concept in survival analysis is the hazard function or hazard rate, $h(t)$. This is the probability that an event will occur at a particular point in time given that the event has yet to occur. In terms of the analysis here, the event in question is the removal of the leader from office. The hazard rate has two components. The first is a set of covariates that are hypothesized to systematically affect the timing of an event. The second is the baseline hazard function that indicates the rate of event occurrence when all the covariates are zero, that is, the baseline hazard reflects how the rate of event occurrence changes with time only.

We employ a Cox model with time-varying covariates as this allows us to estimate the effect of the covariates on the hazard rate without requiring us to specify a particular parametric form for the baseline hazard. Recall that our argument suggests that when capital is mobile, political survival should be a function of an interaction between central bank independence and the choice of the exchange rate regime. Specifically, our model uses the flexible exchange rate with an independent central bank as the baseline case. According to our theory, leaders will possess the ability to control neither monetary nor fiscal policy under these circumstances. The hazard of being removed from office, therefore, is at its highest. In contrast, when a leader confronts a flexible exchange rate and a dependent central bank she can use monetary policy for survival-maximizing purposes. Alternatively, when a leader confronts an independent central bank and a fixed exchange rate, she can use fiscal policy to enhance her political survival. Consequently, any combination of monetary institutions other than the baseline case should prove sufficient to reduce the leader's hazard of removal.

The hazard rate typically has the following form: $h(t \mid x)=h_{0}(t) e^{x \beta}$ where $h_{0}(t)$ is the baseline hazard rate and $x \beta$ in our particular case is specified as

$$
\begin{aligned}
\text { Leader Tenure }= & \beta_{1} \text { Fixed Exchange Rate } \\
+ & \beta_{2} \text { Dependent Central Bank } \\
+ & \beta_{3} \text { Fixed Exchange Rate } \\
& \times \text { Dependent Central Bank } \\
& +\beta_{i} \text { Controls }
\end{aligned}
$$

\footnotetext{
${ }^{13}$ Some readers might wonder whether it is appropriate to control for the ideological orientation of the government, but we do not believe this is necessary. While partisan orientation of government might be related to the choice of monetary institutions, we are unaware of a literature that claims that partisan orientation influences leader survival.
}

An important assumption underpinning use of hazard models is the proportional hazards assumption, which holds that the effect of the covariates in the specified model does not change over time (Box-Steffensmeier and Jones 2004). In our case, however, a test of the Schoenfeld residuals indicates that the proportional hazards assumption is violated. Specifically, the chi-squared statistic is 7.96, with a $p$-value of .047 . Thus, we reject the null hypothesis of no relationship between the residuals and time. ${ }^{14}$ Because the proportional hazards assumption is violated, we must condition the effect of the these explanatory variables on time (Box-Steffensmeier and Zorn 2001). Thus, we revise our model of the hazard rate as follows:

Leader Tenure $=\beta_{1}$ Fixed Exchange Rate

$+\beta_{2}$ Dependent Central Bank

$+\beta_{3}$ Fixed Exchange Rate $\times$ Dependent Central Bank

$+\beta_{4}$ Fixed Exchange Rate $\times$ Time

$+\beta_{5}$ Dependent Central Bank $\times$ Time

$+\beta_{6}$ Fixed Exchange Rate $\times$ Dependent Central Bank $\times$ Time

$$
+\beta_{i} \text { Controls }
$$

Now the coefficient on the variable for a dependent central bank, for example, indicates the effect of low central bank independence on leader survival when the leader has just entered office and when the exchange rate is flexible. Similarly, the coefficient on the variable for a fixed exchange rate regime tells us the effect of fixed exchange rates at the beginning of a leader's term when the central bank is independent.

Table 3 presents our estimates of this model. Model 1 contains only the key independent variables, while Models 2-4 each add in one of the control variables. Finally, Model 5 includes all of the controls in the same model. Notice that our model specifications do not include the measure for time by itself. Normally, we would include all constitutive terms that comprise an interaction term separately as well. As the underlying hazard rate is a function of time, though, doing so would lead to perfect collinearity.

In all five models, the coefficients indicate the effect of the covariates on the baseline hazard. A positive coefficient indicates that the covariate in question increases the hazard rate or, more intuitively, reduces the length of a leader's tenure. Conversely, a negative coefficient implies that the covariate reduces the hazard rate or increases the leader's time in office. Note that the coefficients on the interaction terms that include Time are all

\footnotetext{
${ }^{14}$ Individual Schoenfeld residual tests are difficult to interpret in this case because the two key covariates also appear in the interaction term. However, as both of these key variables are dichotomous, we have the ability to identify the exact reason behind the rejections of the global test. Specifically, we rerun the model with dummy variables for the three categories of (i) fixed exchange rate and a dependent central bank; (ii) fixed exchange rate and an independent central bank; and (iii) flexible exchange rate and a dependent central bank. The final category (flexible exchange rate and an independent central bank) is treated as the omitted category. Doing this shows that the variable for fixed exchange rates and a dependent central bank violates the proportional hazards assumption (a chi-squared statistic of 6.12 , which is statistically different from zero at the 0.01 confidence level). This indicates that it is the interaction of the central bank independence and exchange rate regime variables that is causing the violation of the proportional hazards assumption. As both of our key variables, therefore, violate the proportional hazards assumption, we need to interact all three covariates (exchange rate regime; central bank independence status; and their interaction) with time. None of the individual tests of Schoenfeld residuals for our control variables violated the $\mathrm{PH}$ assumption.
} 
TABLE 3. The Effect of Monetary Institutions on Survival Time in the post-Bretton Woods Era (1971-1999)

\begin{tabular}{|c|c|c|c|c|c|}
\hline Independent Variables & $\begin{array}{l}\text { (1) Main } \\
\text { Model }\end{array}$ & $\begin{array}{l}\text { (2) Main } \\
\text { Model Controlling } \\
\text { for Premier-Timed } \\
\quad \text { Elections }\end{array}$ & $\begin{array}{l}\text { (3) Main Model } \\
\text { Controlling for } \\
\text { Number of Districts }\end{array}$ & $\begin{array}{l}\text { (4) Main Model } \\
\text { Controlling for } \\
\text { Single-party Majority } \\
\text { Governments }\end{array}$ & $\begin{array}{l}\text { (5) Main Model } \\
\text { w/All Controls }\end{array}$ \\
\hline \multicolumn{6}{|c|}{ Dependent variable: tenure of leader (in years) } \\
\hline Fixed exchange rate & $2.90(0.84) * * *$ & $2.64(0.84)^{* * *}$ & $2.99(0.85) * * *$ & $2.86(0.84) * * *$ & $2.48(0.86) * * *$ \\
\hline Dependent central bank & $3.39(0.83)^{* * *}$ & $3.19(0.83)^{* * *}$ & $3.38(0.83) * * *$ & $3.40(0.83) * * *$ & $3.17(0.83) * * *$ \\
\hline $\begin{array}{l}\text { Fixed exchange rate } \times \text { dependent } \\
\text { central bank }\end{array}$ & $-2.56(0.91) * * *$ & $-1.78(0.93) *$ & $-2.59(0.91) * * *$ & $-2.58(0.91)^{* * *}$ & $-1.74(0.94)^{*}$ \\
\hline Fixed exchange rate $\times$ tenure & $-0.57(0.13) * * *$ & $-0.51(0.13)^{* * *}$ & $-0.57(0.13)^{* * *}$ & $-0.57(0.13)^{* * *}$ & $-0.52(0.13) * * *$ \\
\hline Dependent central bank $\times$ tenure & $-0.59(0.14)^{* * *}$ & $-0.58(0.14) * * *$ & $-0.59(0.14)^{* * *}$ & $-0.60(0.14)^{* * *}$ & $-0.59(0.14) * * *$ \\
\hline $\begin{array}{l}\text { Fixed exchange rate } \times \text { dependent } \\
\text { central bank } \times \text { tenure }\end{array}$ & $0.48(0.16)^{* * *}$ & $0.46(0.16)^{* * *}$ & $0.48(0.16)^{* * *}$ & $0.48(0.16)^{* * *}$ & $0.48(0.16)^{* * * *}$ \\
\hline Premier-timed elections & & $0.94(0.28) * * *$ & & & $1.07(0.29) * * *$ \\
\hline Ln (number of electoral districts) & & & $-0.05(0.07)$ & & $0.4(0.07)$ \\
\hline Single-party majority governments & & & & $-0.11(0.25)$ & $-0.45(0.26)^{*}$ \\
\hline Log likelihood & -450.6 & -444.5 & -450.3 & -450.5 & -442.9 \\
\hline Observations & 654 & 654 & 654 & 654 & 654 \\
\hline
\end{tabular}

(Notes. Cox proportional hazards estimates; standard errors in parentheses. The Efron method is employed for handling ties. Data are based on 149 leaders from 19 OECD countries between 1972 and 1999.

$* p<.10 ; * * p<.05 ; * * * p<.01$ (two-tailed).)

significant, which provides additional evidence that the proportional hazard assumption is violated (Cleves, Gould, Gutierrez, and Marchenko 2008:198).

The usefulness of the results in Table 3, however, is limited due to the interaction terms. As mentioned earlier, the coefficient on Fixed Exchange Rate only tells us the effect of having a fixed exchange rate regime when the central bank is independent (that is, Dependent Central Bank is equal to 0) and when tenure is equal to zero. To present the results in a more substantively meaningful way, we graph the percentage change in the hazard rate associated with a change in our covariates Fixed Exchange Rate and Dependent Central Bank over time. To calculate the effect of a change in a covariate in terms of a percentage change in the hazard rate, we use the following formula:

$$
\% \Delta h(t)=\left[\frac{e^{\beta\left(x_{i}=X_{2}\right)}-e^{\beta\left(x_{i}=X_{1}\right)}}{e^{\beta\left(x_{i}=X_{1}\right)}}\right] \times 100
$$

where $X_{1}$ and $X_{2}$ are, respectively, the values of the covariate before and after the change.

Hypothesis 1 states that when capital is mobile and the central bank is independent, having fixed rather than flexible exchange rates should decrease a leader's hazard rate (increase the leader's time in office). To evaluate this hypothesis, given the interaction with time, we need to calculate the estimated effect of a change in institutions on the hazard rate over a plausible range of the leader's tenure. For example, in Figure 1, we plot the percentage change in the hazard rate associated with a change from a flexible to a fixed exchange rate (given mobile capital and an independent central bank) from the third to the fifteenth year in office for the leaders in our sample. ${ }^{15}$

\footnotetext{
${ }^{15}$ We plot this period for a couple of reasons. One is that we do not expect that these tools will make a difference for leaders in the first few years of their term; they should matter most when survival is more tenuous, which we expect to be the case later in a leader's term The other is simply for ease of presentation; for a couple of the graphs the percentage change is large (and positive) in the first year of a leader's term and it makes the relevant details in the graph more difficult to ascertain.
}

In Figures 1 and 2, the solid black line indicates how the percentage change in the hazard rate associated with a change in the exchange rate regime changes with the length of time in office. The $95 \%$ confidence intervals around this line allow us to determine the conditions under which the estimated difference between flexible and fixed exchange rate is statistically significant. ${ }^{16}$ All other variables are held at their means or modes. The percentage change in the hazard rate is statistically significant whenever the upper and lower bounds of the confidence interval are both above (or below) the zero line. The figure shows that the percentage change in the hazard rate is negative and significant after a leader has been in office for 7 years. At this point, leaders under fixed exchange rate regimes face the reduced hazard of being removed from office that was anticipated by Hypothesis 1.

Hypothesis 2 states that when capital is mobile and exchange rates are flexible, incumbents in countries with dependent central banks should survive longer in office (have lower hazard rates) than those with independent central banks. Figure 2 shows that when the exchange rate is flexible, leaders confronting dependent central banks face a lower hazard of leaving office than those confronting an independent central bank when they are later in their tenure. Specifically, the percentage change in the hazard rate is negative and significant after a leader has been in office for 7 years. In other words, having a dependent rather than an independent central bank (with a flexible exchange rate) has the hypothesized effect when a leader tries to stay in power beyond her seventh year in office. This is remarkably similar to the evidence that we found in support of Hypothesis 1 .

While it is important to show that the changes in institutions relevant to Hypotheses 1 and 2 have statistically significant effects in the hypothesized directions (for long-serving leaders), it is also important to determine whether the magnitude of these estimated effects are sub-

\footnotetext{
${ }^{16}$ Confidence intervals are based on simulations using 10,000 draws from the estimated coefficient vector and variance-covariance matrix.
} 


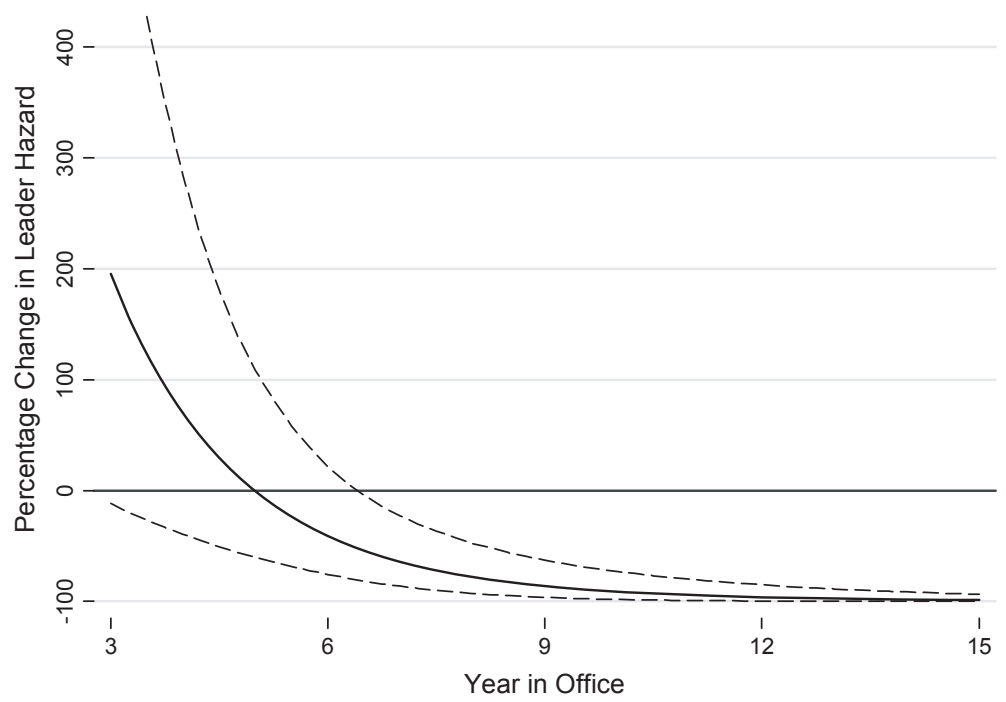

FIg 1. Percentage Change in Hazard Rate when Leader has Fixed Instead of Flexible Exchange Rate Regime, when Central Bank is Independent

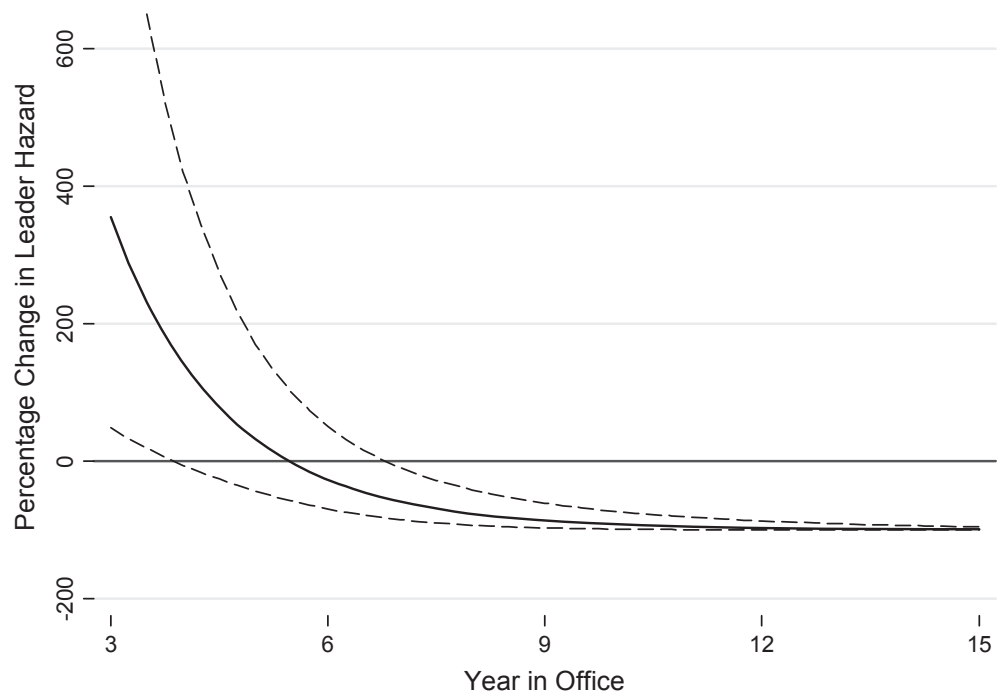

FIg 2. Percentage Change in Hazard Rate when Leader has Dependent Central Bank instead of Independent, when Exchange Rate is Flexible

stantively important. To set a baseline for comparison, we look at the case where leaders control neither monetary nor fiscal policy. The hazard rate for leaders in their seventh year in office in countries with highly independent central banks and flexible exchange rates (with all other variables held at their mean or mode) is 3.42 . In contrast, and consistent with Hypothesis 1, leaders in countries that are the same in all relevant ways to this baseline except that they maintain a commitment to fixed exchange rates (thereby granting leaders effective control over fiscal policy) are estimated to face a hazard rate less than half as large (1.22, a $64.3 \%$ decrease in the hazard rate). Similarly, and consistent with Hypothesis 2, leaders in countries that are the same in all relevant ways to the baseline case except that central bank independence is low (thereby granting leaders effective control over monetary policy) are also estimated to a hazard rate less than half as large (1.38, a $59.6 \%$ decrease in the hazard rate) as the baseline case.
This suggests that from the standpoint of survival-maximizing leaders who find themselves in the baseline case where they possess neither the ability to control monetary policy (because the central bank is independent) nor the ability to control fiscal policy (because capital is mobile and the exchange rate is flexible), a reduction in central bank independence or a switch to a fixed exchange rate regime is equally effective in accomplishing the goal of prolonging their tenure in office. ${ }^{17}$

It should be noted that the results in Figures 1 and 2 indicate that during an incumbent's first few years in

\footnotetext{
${ }^{17}$ We also have testable implications about cases of low central bank independence and fixed exchange rates. If the exchange rate is fixed, we would expect no significant difference between the hazard rates between leaders in low central bank independence and high central bank independence countries. If the central bank is independent, a change from flexible exchange rates to fixed exchange rates is not expected to have any effect on the leader's hazard of being removed from office. We find both expectations hold and can provide the relevant figures upon request.
} 
office, central bank dependence, as well as a fixed exchange rate regime, increases the likelihood of being expelled from office. We find this a bit surprising but it might be explained by the fact that incumbents who can manipulate monetary and fiscal policy for political purposes are more likely to experience the consequences of their predecessors' short-sighted policies in the early days of their tenure. The more interesting result, we think, is that the hypothesized effects of monetary institutions on leader tenure seem to kick in only after seven years. In the discussion section below, we point to some literature that might shed light on these findings.

Earlier, we expressed concerns that a set of political variables might be correlated both with leader survival and the choice of monetary institutions. Models 2-5 in Table 3 are meant to address such concerns. Note that all of the coefficients connected to monetary institutions are quite stable across changes in specification. The coefficients for fixed exchange rates and dependent central bank experience moderate attenuation when we control for these other institutional variables, but the coefficients on the interaction terms are remarkably stable. This suggests that if we were to create figures like Figures 1 and 2 based on these alternative specifications, the picture would remain largely the same. The size of the positive effect of institutional changes would be diminished somewhat and the point at which these institutions reduce leader's risk of removal would occur slightly earlier. But otherwise the story is the same. This suggests that the specification shown in Model 5 in Table 3 is not an unreasonable specification upon which to base our inferences.

It should also be noted that political survival in the post-Bretton Woods era appears to be influenced by some of the control variables discussed earlier. Most pronounced is the effect of endogenous elections, although the direction of the effect may be surprising to some readers who are familiar with the argument that better economic performance makes incumbent governments more likely to call early elections (Palmer and Whitten 2000). Leaders who have the ability to influence when elections are called are at roughly twice the hazard of being removed as leaders without the ability to time elections to take advantage of positive economic shocks. On the one hand, if we think of manipulation and "surfing", as alternative instruments in a survival-maximizing leader's arsenal, it is perhaps surprising that leaders with only one instrument survive longer than those with two. On the other hand, Smith (1996) presents a model in which voters punish incumbents who call snap elections because they infer that incumbents have private information that the economy is about to experience a downturn. This, of course, suggests that incumbents should not, in equilibrium, call snap elections. But since they sometimes do, Smith's model may explain why leaders who have the legal power to surf may, on average, be at greater risk of being removed from office than those who do not. Another possibility is that legislatures in such systems may have mechanisms for removing leaders that may be absent in many systems with exogenously timed elections. Put differently, this result may be due to cabinet instability that is unrelated to the management of the economy. $^{18}$

18 If our goal was to assess the effects of premier-timed elections on political survival, however, we might have wished to control for other factors that are correlated with premier-timed elections that might also effect survival.
Recall that we considered competing arguments regarding the effect of government type on leader survival. On the one hand, single-party majority governments are expected to be capable of acting quickly and decisively in pursuit of survival-maximizing policies. In addition, some have argued that commitments to central bank independence will lack credibility if the government consists of a single-party majority. Both of these factors suggest that incumbents in countries with single-party majority governments should face less of a risk of replacement. On the other hand, governments in such circumstances will find it harder to share the blame when things go poorly. The evidence in columns four and five of Table 3 suggest that the leaders in single-party government situations will face hazard rates that are lower than leaders in countries with other government types. This might suggest that the ease of policy making and/or the ability to override nominally independent central banks may trump the dangers associated with high clarity of responsibility, but we are reluctant to read too much into these results because the coefficient in Model 4 was not significant and the one in Model 5 was only significant at the $90 \%$ confidence level. Finally, we find no evidence of a relationship between the number of electoral districts and the hazard rate.

Turning now to the third hypothesis, we examine whether leaders presiding over good economic times actually survive longer than those that do not. ${ }^{19}$ As before, we interact the key covariate, GDP Growth, with time. Table 4 presents results from two hazard models germane to this concern. This table reports estimates from a hazard model that interacts GDP growth with tenure in office. Our expectation is that increased economic growth reduces the leader's risk of being removed from office.

A figure analogous to Figures 1 and 2-not shown here for reasons of space-suggests that the data are consistent with this expectation. Shortly after year three, a $1 \%$ point increase in the growth rate is associated with a decline in the hazard rate. As the leader's tenure approaches year six, this decline becomes statistically significant. The magnitude of this change is also substantively important. By year seven, a one percentage point increase in the growth rate is associated with a $26.2 \%$ decline in the hazard rate. Interestingly, this is very close to the estimated effect of the onset of an election when the exchange rate is flexible and the central bank is dependent or when the exchange rate is fixed and capital is fully mobile (see Clark 2003:163, 164).

Note also that GDP growth appears to influence leader survival at roughly the same point in a leader's tenure that we found the ability to manipulate monetary or fiscal policy to be felicitous for leader survival. Good economic performance appears to buoy leader survival starting in year six, and the survival enhancing effects of control over monetary and fiscal policy are statistically discernible at about year seven. Thus, the ability to manipulate the macroeconomy helps leaders only at the point in their tenure where poor macroeconomic performance has an appreciable affect on leader survival.

\footnotetext{
19 Previous work suggests that leaders presiding over good economic times will call early elections if they have the ability to do so (Palmer and Whitten 2000). The assumption is that these leaders are subsequently rewarded at the polls. Our analysis tells us whether leaders who enjoy endogenous election timing stay in power longer than those who do not, as well as whether this benefit holds when leaders' terms do not always end with elections.
} 
TABLE 4. The Effect of Economic Growth on Survival Time in the post-Bretton Woods Era

\begin{tabular}{lc}
\hline Independent Variables & Main Model \\
\hline \multicolumn{1}{c}{ Dependent variable: tenure of leader (in years) } \\
GDP growth rate & $0.286(0.121)^{* *}$ \\
GDP growth $\times$ tenure & $-0.094(0.034)^{* * *}$ \\
Log likelihood & -179.8 \\
Observations (leaders) & 266 \\
\hline
\end{tabular}

(Notes. Cox proportional hazards estimates; standard errors in parentheses. The Efron method is employed for handling ties. Data are based on leaders from 19 OECD countries between 1972 and 1999.

$* p<.10 ; * * p<.05 ; * * * p<.01$ (two-tailed).)

\section{Discussion: Why Long-Serving Leaders?}

It is clear that context matters-not all leaders have the ability to manipulate the economy (Clark and Hallerberg 2000), and not all leaders have the incentive to do so at all times (Schultz 1995). The above results are striking, though, in that they suggest another contextual feature that plays a role, namely length of time in power. Economic performance, and the ability to manipulate macroeconomic policy, matters for long-serving leaders but does not have an effect prior to the eighth year in office. Stated differently, we find that having the ability to manipulate the economy could only enhance the survival of the 24 leaders (comprising 114 of 649 leader years) in our sample who were in office seven or more years. That such a low number of leaders' survival can be enhanced by possessing the tools of macroeconomic policy actually makes our finding even more important-this shows that what the conventional wisdom suggests should benefit all (or, at least, most) leaders, actually benefits very few.

But why would long-serving leaders be especially vulnerable? It is beyond the scope of the study to fully engage this question. However, we wish to offer in this section some possible motivational and structural explanations that can be subjected to proper testing at a later time.

Anecdotal evidence suggests that leaders may be most motivated to manipulate the economy late in their tenures in response to the accusation of stale policies. For example, the biggest challenge facing Margaret Thatcher prior to her 1987 re-election was to continually rebut "anyone [who] hoped to attack the Conservative Party for running out of ideas after two periods of office." 20 Similarly, in a key debate prior to the 1993 legislative elections, the chief Spanish opposition rival, Jose Marie Anzar Lopez, leveled the following accusation against the long-serving Spanish Prime Minister, Felipe Gonzalez; "you have lost the confidence of the nation and your government has run out of ideas."21 During the campaign prior to the election that eventually ended Helmut Kohl's 16-year tenure as German Chancellor, The Economist magazine editorialized that change was needed because, quite simply, Kohl was "out of ideas." 22 What can long-serving leaders do to counter the accusation of having "run out of ideas," particularly when their long tenures mean such claims might actually be true? In

\footnotetext{
${ }^{20}$ Quoted from speech to unveiling the Conservative party's manifesto (Time magazine, June 1, 1987).

21 "Gonzalez wins by default in lackluster clash." The Independent (London), June 2, 1993. p. 10.

${ }_{22}$ "Chancellor Schröder?" The Economist, March 7, 1998, p. 15.
}

short, although leaders may attempt to reposition their party or unveil new policies, it appears that these leaders are the most likely to resort to inducing political business cycles.

Systematic evidence also suggests that long-serving leaders face great (if not the greatest) difficulty in retaining office. Focusing on American presidential elections, Abramowitz (2004:274) includes in his "time for a change" model of presidential elections a variable capturing whether the current president's party has been in office for more than one term. Using data on all Presidential elections from 1948 to 2000, Abramowitz finds that the president's party being in office for more than one term has a statistically significant negative impact on the incumbent vote share in the next election. As Abramowitz (1988:844) states, "the candidate of the incumbent party will do worse if his party has controlled the White House for 8 years or longer: the longer a party has been in power, the more likely the public is to feel that 'it's time for a change'.',

Other scholars, while agreeing that incumbents do pay a "cost of ruling", 23 are less convinced by the hypothesis that this is caused because "voters have a taste for change" (Paldam and Skott 1995:160). As Paldam and Skott (1995) state, "It is a common hypothesis in popular writings that from time to time voters want to see new faces...[but] this hypothesis is hard to prove or disprove", (Paldam and Skott 1995:160). Thus, Paldam and Skott (1995) essentially dismiss this argument when explaining the cost of voting. Similarly, in his book-length study of government duration, Warwick (1994:104) only briefly alludes to the possibility of voters wanting something new, before turning to other factors: "it may be the case that the sources of the rising hazard lie with factors that are unmeasured, perhaps inherently unmeasurable: a gradual disillusionment among government ranks that comes with policy errors or failures, a general tendency for the popularity of governments to decline over time, and the like." Stevenson $(2002: 157,158)$ presents an explanation for the cost of ruling that ignores the notion of a "taste for change" altogether, although he clearly says that it is a "well established empirical fact: that the longer an incumbent government has been in power, the more votes it loses." Note that this is not simply a reference to a cost of being in power, but a statement about how this cost grows over time: "the size of the negative incumbency effect tends to increase with the length of time the incumbent cabinet has been in power" (Stevenson 2002:158). Although we are looking at the leaders, not cabinets per se, Stevenson's finding is consistent with our own finding: the leaders that Stevenson would expect to be most susceptible to losing votes are also the ones most likely to benefit from the ability to induce political business cycles.

Although such "long-serving leaders" may have the greatest incentive to induce political business cycles, there may also be structural reasons that explain why they experience the greatest benefit from the ability to induce political business cycles. Consider a series of hypothetical leaders, each removed from office at different times of their tenure (some early, some late). First, leaders who are removed from office in their first year are not likely

\footnotetext{
${ }^{23}$ Many scholars have found evidence suggesting that incumbents lose votes. For a small selection of literature showing evidence of the negative incumbency hypothesis, see, for example, Rose and Mackie (1983), Strøm (1985), Palmer and Whitten (1999), or Narud and Valen (2008).
} 
to have been able to propose, let alone enact and implement, a change in macroeconomic policy. Second, given the time lag between the implementation of expansionary fiscal or monetary policy and its real effect on the economy, it is unlikely that a leader removed in their second or third year in office would have the ability to manipulate the economy in such a way as to induce favorable voter sentiment. ${ }^{24}$ Moreover, leaders in the early years of their tenure are able to blame difficult economic times on the policies of their predecessors; thereby eliminating a need to manipulate the economy solely for political gain.

But what about leaders who are beyond these initial years of tenure? These leaders are not in a post-election "honeymoon" period and, most likely, are now approaching an election (either because it is on a fixed cycle, as in the United States, or because they are reaching the maximum length of time between elections, as in the United Kingdom). Thus, it is leaders beyond their first three or 4 years in office who would be most likely to have both the ability and the incentive to pull the levers of monetary and fiscal policy.

\section{Conclusion}

We present robust evidence that when political leaders lack control of either monetary or fiscal policy, they stand a higher risk of being removed from office when they have been in office for at least 7 years. In addition, we present evidence that only leaders who stay in office for at least 6 years appear to be imperiled by economic downturns. Effective manipulation appears to occur only when incumbents have the means and the motive and are sufficiently vulnerable due to the costs of holding office.

There is a large literature on economic voting that suggests that incumbents presiding over economic downturns are more likely to be removed from office by retrospective voters than incumbents in power during favorable economic times. The literature on political business cycles suggests that the threat of suffering such a fate induces incumbents to engineer macroeconomic expansions during pre-electoral periods. The current study suggests that the literatures connected by the above logic both understate and over-generalize the link between economics and politics. They understate the link between economics and politics because elections are only one way in which unpopular leaders are removed from office in democracies. In fact, in our sample, more leaders leave office through resignation than by losing elections. This may explain why, in the words of an influential scholar of economic voting, "economic effects on election outcomes do not qualify as a 'robust fact' about elections" (Anderson 2007:286). Indeed, Grafstrom (2011) shows that only a tiny fraction of models estimating the conditional effect of economic outcomes on incumbent vote shares produce correctly signed, statistically significant coefficients. Could it be that the macro evidence for economic voting is virtually non-existent because this literature has mistaken one mechanism by which poor performing leaders are removed from office for the mechanism of leader removal? Losing an election

\footnotetext{
${ }^{24}$ The possibility of fiscal foresight, in which economic actors change behavior in response to a known change in tax policy, is discussed extensively by Leeper, Walker \& Yang (2009). However, voters at large may still adopt a "believe it when I feel it" approach, that is, they must have directly received the benefits from the change in policy before it can induce a change in voting behavior.
}

is not even the modal way in which leaders are removed from office, so while losing an election is sufficient for being removed from power, it is clearly not necessary. Consequently, existing tests of the economic voting hypothesis constitute a misspecified attempt to test the broader hypothesis that political survival is imperiled by poor macroeconomic outcomes. As a result, doubt has been cast, prematurely we think, on the operation of mechanisms of accountability in advanced industrial democracies. We have not provided an adequate test of this broader argument, but hope the results on the link between economic growth and political survival are suggestive of the way forward.

The existing literatures may over-generalize the link between economics and politics in two ways. First, while all leaders are at risk of being removed from office during economic hard times late in their tenure, not all leaders possess the macroeconomic policy instruments that would allow them to try to stave off hard times. Second, it appears that the state of the economy has a pronounced effect on the incumbent's survival chances only when incumbents have been in power for some time. The desire to manipulate the economy may be necessary, but it is not sufficient. Long-lived leaders with control of neither monetary nor fiscal policy are stuck between a rock and a hard place and, therefore, run a higher risk of being removed from office. Our results suggest that leaders who use these tools too early, though, will not help themselves either.

One consequence of this predicament is that leaders who are vulnerable due to a long term in office and who lack access to monetary institutions that would allow them to manipulate the economy may be more apt to cast about for riskier ways to prolong their political lives. For example, if leaders benefit from a "rally around the flag effect", they might be particularly tempted to engage in diversionary foreign policy acts late in their terms if they lack the capacity to manipulate the macroeconomy. As it is plausible that leaders might have a hierarchy of survival-maximizing strategies, it is plausible they would engage in macroeconomic manipulation if that option is available and diversionary war only when it is not. This context conditionality may explain why unconditional tests of the diversionary war hypothesis have produced contradictory results.

Together, the above observations suggest that the leaders face an increased risk of being removed from office for poor economic policy performance independent of the onset of elections. Consequently, leaders in "premiertimed" systems are not likely to be content to "surf" on exogenously determined economic waves. They too have incentives to manipulate the economy. It is, therefore, significant that the results reported in this study are drawn from a sample in which very few countries have entirely fixed electoral calendars.

Interestingly, the combination of institutions that leaves incumbents without the ability to manipulate the macroeconomy for their political survival (independent central bank, mobile capital, and flexible exchange rates) is precisely the set of institutions frequently trumpeted by international financial institutions such as the International Monetary Fund. It is not surprising that the Fund would like member countries to adopt institutions that make it difficult for economic policy to be used for political purposes, but our results imply that survival-maximizing leaders would have reasons to be reluctant to adopt such institutions. 


\section{References}

Abramowitz, Alan I. (1988) An Improved Model for Predicting Presidential Election Outcomes. PS: Political Science and Politics 21: 843847.

Abramowitz, Alan I. (2004) Voice of the People: Elections and Voting in the United States. New York: McGraw Hill.

Anderson, Christopher J. (2007) The End of Economic Voting? Contingency Dilemmas and the Limits of Democratic Accountability. Annual Review of Political Science 10: 271-296.

Andrews, David. (1994) Capital Mobility and State Autonomy: Toward a Structural Theory of International Monetary Relations. International Studies Quarterly 38: 193-218.

Bienen, Henry, and Nicolas Van de Walle. (1991) Of Time and Power: Leadership Duration in the Modern World. Stanford, CA: Stanford University Press.

Box-Steffensmeier, Janet M., And Bradford S. Jones. (2004) Event History Modeling: A Guide for Social Scientists. New York: Cambridge University Press.

Box-Steffensmeier, Janet M., And Christopher J. W. Zorn. (2001) Duration Models and Proportional Hazards in Political Science. American Journal of Political Science 45: 951-967.

Brownlee, Jason. (2009) Portents of Pluralism: How Hybrid Regimes Affect Democratic Transitions. American Journal of Political Science 53: 515-532.

Chiozza, Giacomo, and Hein Goemans. (2004) International Conflict and the Tenure of Leaders: Is War Still Ex Post Inefficient? American Journal of Political Science 48 (3): 604-619.

Clark, William Roberts. (2003) Capitalism, Not Globalism: Capital Mobility, Central Bank Independence and the Political Control of the Economy. Ann Arbor, MI: University of Michigan Press.

Clark, William Roberts, and Mark Hallerberg. (2000) Mobile Capital, Domestic Institutions, and Electorally Induced Monetary and Fiscal Policy. American Political Science Review 94: 323-346.

Cleves, Mario A., William W. Gould, Roberto G. Gutierrez, and Yulia U. Marchenko. (2008) An Introduction to Survival Analysis Using STATA. TX: STATA Press.

Conrad, Courtenay R., and Sona N. Golder. (2010) Measuring Government Duration and Stability in Central Eastern European Democracies. European Journal of Political Research 49: 119-150.

Cukierman, Alex, Steven B. Webb, And Bilin Neyapti. (1992) Measuring the Independence of Central Banks and Its Effect on Policy Outcomes. World Bank Economic Review 6: 353-398.

Duch, Raymond M., and Randolph T. Stevenson. (2008) The Economic Vote: How Political and Economic Institutions Condition Election Results. New York, NY: Cambridge University Press.

Franzese, Robert. (2002) Macroeconomic Policies of Developed Democracies. New York, NY: Cambridge.

Franzese, Robert, and Irfan Nooruddin. (2004) The Effective Constituency in (Re)Distributive Politics. Conference Paper presented at Midwest Political Science Association Annual Meeting.

Geoffrey, Garrett. (1998) Partisan Politics in the Global Economy. New York, NY: Cambridge University Press.

Goemans, Hein E., Kristian Skrede Gleditsch, and Giacomo ChiozzA. (2009) Introducing Archigos: A Dataset of Political Leaders. Journal of Peace Research 46: 269-283.

Golder, Matt. (2005) Democratic Electoral Systems Around the World, 1946-2000. Electoral Studies 24: 103-121.

Grafstrom, Cassandra. (2011) Clarifying the Clarity of Responsibility Thesis. Manuscript, University of Michigan.

Kayser, Mark Andreas. (2005) Who Surfs, Who Manipulates? The Determinants of Opportunistic Election Timing and Electorally Motivated Economic Intervention. American Political Science Review 99: 17-28.

Kayser, Mark Andreas. (2006) Trade and the Timing of Elections. British Journal of Political Science 36: 437-457.

Keech, William R. (1995) Economic Politics: The Costs of Democracy. New York, NY: Cambridge.
Keefer, Philip, and David Stasavage. (2002) Checks and Balances, Private Information, and the Credibility of Monetary Commitments. International Organization 56: 751-774.

Laver, Michael, and Kenneth A. Shepsle. (1991) Divided Government: America Is Not 'Exceptional'. Governance 4: 250-269.

Laver, Michael, And Kenneth A. Shepsle. (1996) Making and Breaking Governments: Cabinets and Legislatures in Parliamentary Democracies. New York: Cambridge University Press.

Leblang, David, and William Bernhard. (2002) Political Parties and Monetary Commitments. International Organization 56: 803-831.

Leeper, Eric M., Todd B. Walker, and Shu-Chun S. YAng. (2010) Government Investment and Fiscal Stimulus. IMF Working Paper $\mathrm{WP} / 10 / 229$.

MacRae, C. Duncan. (1977) A Political Model of the Business Cycle. Journal of Political Economy 85: 239-263.

Moser, Peter. (1999) Checks and Balances, and the Supply of Central Bank Independence. European Economic Review 43: 1569-1593.

Mundell, Robert A. (1963) Capital Mobility and Stabilization Policy Under Fixed and Flexible Exchange Rates. Canadian Journal of Economic and Political Science 29: 475-485.

Narud, Hanne Marthe, and Henry Valen. (2008) Coalition Membership and Electoral Performance. In Cabinets and Coalition Bargaining: The Democratic Life Cycle in Western Europe, edited by Kaare Strøm, Wolfgang C. Müller, and Torbjörn Bergman. Oxford: Oxford University Press.

Nordhaus, William D. (1975) The Political Business Cycle. The Review of Economic Studies 42: 169-190.

Paldam, Martin, and Peter Skott. (1995) A Rational-Voter Explanation of the Cost of Ruling. Public Choice 83: 159-172.

Palmer, Harvey D., and Guy D. Whitten. (2000) Government competence, economic performance and endogenous election dates. Electoral Studies 19: 413-426.

Powell, G. Bingham. (2000) Elections as Instruments of Democracy: Majoritarian and Proportional Visions. New Haven, CT: Yale University Press.

Quinn, Dennis. (1997) The Correlates of Change in International Financial Regulation. American Political Science Review 91: 531-551.

Rose, Richard, and Thomas Mackie. (1983) Incumbency in Government: Asset or Liability. In Western European Party Systems, edited by H. Daalder, and P. Mair. London and Beverly Hills: Sage Publications, 1983, 115-137.

Schultz, Kenneth A. (1995) The Politics of the Political Business Cycle. British Journal of Political Science 25: 79-99.

Smith, Alastair. (1996) Endogenous Election Timing in Majoritarian Parliamentary Systems. Economics and Politics 8: 85-110.

Smith, Alastair, and Fiona McGillivray. (2008) Punishing the Prince: A Theory of Interstate Relations, Political Institutions, and Leader Change. Princeton, NJ: Princeton University Press.

Stevenson, Randolph T. (2002) The Cost of Ruling, Cabinet Duration, and the "Median Gap" Model. Public Choice 113: 157-178.

Strøm, KaAre. (1985) Party Goals and Government Performance in Parliamentary Democracies. American Political Science Review 79: 738754.

Tufte, Edward R. (1978) Political Control of the Economy. Princeton, NJ: Princeton University Press.

Warwick, Paul V. (1994) Government Survival in Parliamentary Democracies. New York: Cambridge University Press.

Wевв, M. (1991) International Economic Structures, Government Interests and International Co-ordination of Macroeconomic Adjustment Policies. International Organization 41: 335-370.

Weingast, Barry R., Kenneth A. Shepsle, and Christopher Johnsen. (1981) The Political Eocnomy of Benefits and Costs: A Neoclassical Approach to Distributive Politics. Journal of Political Economy 89: 642-664.

Whitten, Guy D., And Harvey D. Palmer. (1999) Cross National Analyses of Economic Voting. Electoral Studies 18: 49-67.

Woldendrop, JaAp, Hans Keman, and Ian Budge. (2000) Party Government in 48 Democracies (1945-1998). Dordrecht, Netherlands, Boston: Kluwer Academic Publishers. 